\title{
2-Aminothiazole Derivative as a New Class of TrkA Kinase Inhibitor ${ }^{\dagger}$
}

\author{
Jinyeong Kim, Yeoju Moon, and Seung Wook Ham* \\ Department of Chemistry, College of Natural Science, Chung-Ang University, Seoul 156-756, Korea. "E-mail: swham@cau.ac.kr \\ Received March 12, 2011, Accepted April 22, 2011
}

Key Words : 2-Aminothiazole derivatives, TrkA, Kinase inhibitor, Anticancer

Cancer (also called a malignant neoplasm) is a class of diseases in which a group of cells show uncontrolled cell growth, invasion and occasionally metastasis, and is a major public health problem worldwide. However, drug discovery and the development of cancer therapeutics take many years before a patient can benefit from a new drug. This time period is too long and needs to be shortened so patients can benefit quickly from new technologies and product development ideas.

Combinatorial chemistry is a widely used technique for accelerating drug discovery and development, in which tools and technologies from biology and chemistry are used in a parallel manner. It was reported that many 2-aminothiazoles exhibit antitumor activity through the inhibition of kinases, ${ }^{1-3}$ Therefore, in the course of searching for anticancer agents, 2-aminothiazole derivatives were recently prepared by varying the 2-amino position and 5-substituted group in a high-speed parallel format according to the literature procedure, as shown in Scheme 1. ${ }^{4}$ Among synthesized, compound H154 exhibited significant cell growth inhibition against Hep3B cells with an $\mathrm{IC}_{50}$ value of $0.040 \mu \mathrm{M}$ by the [3-(4,5-dimethylthiazol-2-yl)-2,5-diphenyltetrazolium bromide] (MTT) assay. However, the specific cellular mechanism of action of this compound is unclear. ${ }^{5}$

To investigate the mechanism of action and the kinase inhibitory profile of $\mathbf{H 1 5 4}$, the compound was tested on a panel of 109 cancer related kinases using the kinase profiling service at Milipore, ${ }^{6}$ because 2 -aminothiazole derivatives has inhibitory activity against the kinases by competing for the ATP binding site. ${ }^{1-3}$ When the inhibitory activity of this compound was investigated across the different protein kinase at $10 \mu \mathrm{M}$, among the 109 different protein kinases, H154 inhibited the activity of TrkA (Troponyosin-receptor kinase A) significantly. Accordingly, compound H154 was further tested for its ability to activate the 6His-tagged human Trk cytoplasmic domain in a 10 -dose $\mathrm{IC}_{50}$ mode with threefold serial dilutions starting at $1 \mu \mathrm{M}{ }^{7}$ The results showed that $\mathbf{H 1 5 4}$ has significant potency with an $\mathrm{IC}_{50}$ of $13 \mathrm{nM}$, as shown in Figure 1.

Among the Trk kinases inhibitors, staurosporine and its subclass, such as K-252a and CEP-701, have been discovered to be ATP competitive kinase inhibitors with a nonomolar

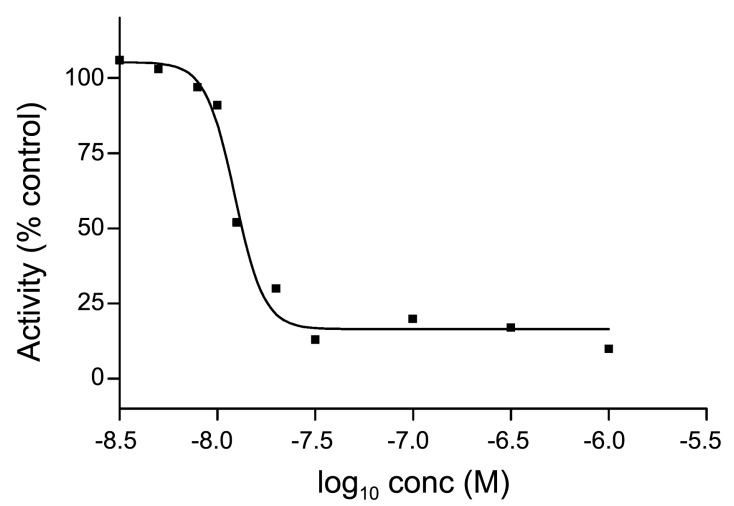

Figure 1. Inhibition of the TrkA kinase activity by compound $\mathbf{H 1 5 4}$. The enzymatic activity of $N$-terminal 6 His-tagged recombinant human TrkA (residues 440 -end, $41 \mathrm{kDa}$ ) was measured in the presence of an increasing concentration of $\mathbf{H 1 5 4}$. The $\mathrm{IC}_{50}$ value of $\mathbf{H 1 5 4}$ (average of 3 determinations) was determined to be $13 \mathrm{nM}$.<smiles>[R]C(=O)Nc1ncc([R])s1</smiles><smiles>CCCCCC(=O)Nc1ncc(-c2ccccc2)s1</smiles>

Scheme 1. Synthetic route of 2-aminothiazole derivatives and structure of H154. 
Table 1. $\mathrm{IC}_{50}$ values of compound $\mathbf{H 1 5 4}$ in various cancer cell lines

\begin{tabular}{ccccccc}
\hline & \multicolumn{6}{c}{$\mathrm{IC}_{50}(\mathrm{nM})$} \\
\cline { 2 - 7 } & \multirow{2}{*}{ A549 } & SK- & SK- & HCT15 & XF498 & A431 \\
& OV-3 & MEL2 & & & \\
\hline H154 & 33.50 & 0.32 & 8.05 & 3.87 & 12.89 & 23.84 \\
Doxorubicin & 2.40 & 51.60 & 1.70 & 35.80 & 20.90 & 2.00 \\
\hline
\end{tabular}

range of $\mathrm{IC}_{50}$ values. ${ }^{8}$ In addition, pyrazole, keto-pyrrolopyrimidine, oxindole, isothiazole, thiazole analogs have been reported to be potent Trk inhibitors. ${ }^{9}$ Although, some compounds have shown promise against prostate and pancreatic cancers ${ }^{10}$ and in clinical trials, ${ }^{11}$ these compounds inhibited a wide range of kinases or were selective among a short panel of kinases. However, when the inhibitory activity of compound H154 was examined across the different 109 protein kinases at $10 \mu \mathrm{M}$, only three enzymes, Abl (53\%), EphA1 (63\%), and ZIPK (61\%), were susceptible to H154 with inhibition exceeding $50 \%$. The other enzymes were unaffected, even at $10 \mu \mathrm{M}$. Moreover, kinase profiling showed that $\mathbf{H 1 5 4}$ at 10 $\mu \mathrm{M}$ did not exhibit inhibitory activity against other tested receptor tysosine kinases, such as ALK, cKit, EGFR, FGFR, IR, PDGFR, Ret, Ron, Ros, and Tie2, indicating $\mathbf{H 1 5 4}$ is a selective TrkA inhibitor.

In the past decade, it was reported that TrkA expression is increased in the late stage prostate cancers. ${ }^{12}$ Recent literature also shows that the over-expression of TrkA is associated with many cancers including malignant melanomas, ${ }^{13}$ ovarian carcinoma, ${ }^{14}$ pancreatic cancer, ${ }^{15}$ and colon cancer. ${ }^{16}$ When the efficiency of the cytotoxic effects on various cells was examined, ${ }^{17}$ compound $\mathbf{H 1 5 4}$ exhibited anti-proliferation effects in the nanomolar concentration range, and more potency against ovary (SK-OV-3), melanoma (SK-MEL2) and colon (HCT15) tumor cells, which overexpress Trk receptors, as shown in Table 1. This indicates that the anti-proliferation effects of $\mathbf{H 1 5 4}$ are due to the inhibition of TrkA.

After the discovery of the involvement of Trks in the biology of cancer, it was suggested that the inhibition of Trk kinases might be beneficial in a clinical oncology setting. The present data show that $\mathbf{H 1 5 4}$ has selectively potent inhibitory activity against Trk receptor tyrosine kinase and has significant anti-tumor efficacy. These results suggest it could, therefore, serve not only as a useful research tool in the Trk-related investigations, but may also have therapeutic value as an anti-cancer agent in Trk-expressing tumors.

Acknowledgments. This work was supported by Basic Science Research Program through the National Research Foundation of Korea (NRF) funded by the Ministry of Education, Science and Technology (2010-0008375).

\section{References and Notes}

1. Kim, K. S.; Kimball, S. D.; Misra, R. N.; Rawlins, D. B.; Hunt, J. T.; Xiao, H. Y.; Lu, S.; Qian, L.; Han, W. C.; Shan, W.; Mitt, T.; Cai, Z. W.; Poss, M. A.; Zhu, H.; Sack, J. S.; Tokarski, J. S.;
Chang, C. Y.; Pavletich, N.; Kamath, A.; Humphreys, W. G.; Marathe, P.; Bursuker, I.; Kellar, K. A.; Roongta, U.; Batorsky, R.; Mulheron, J. G.; Bol, D.; Fairchild, C. R.; Lee, F. Y.; Webster, K. R. J. Med. Chem. 2002, 45, 3905.

2. Misra, R. N.; Xiao, H. Y.; Kim, K. S.; Lu, S.; Han, W. C.; Barbosa, S. A.; Hunt, J. T.; Rawlins, D. B.; Shan, W.; Ahmed, S. Z.; Qian, L.; Chen, B. C.; Zhao, R.; Bednarz, M. S.; Kellar, K. A.; Mulheron, J. G.; Batorsky, R.; Roongta, U.; Kamath, A.; Marathe, P.; Ranadive, S. A.; Sack, J. S.; Tokarski, J. S.; Pavletich, N. P.; Lee, F. Y.; Webster, K. R.; Kimball, S. D. J. Med. Chem. 2004, 47, 1719.

3. Borzilleri, R. M.; Bhide, R. S.; Barrish, J. C.; D'Arienzo, C. J.; Derbin, G. M.; Fargnoli, J.; Hunt, J. T.; Jeyaseelan, R. Sr.; Kamath, A.; Kukral, D. W.; Marathe, P.; Mortillo, S.; Qian, L.; Tokarski, J. S.; Wautlet, B. S.; Zheng, X.; Lombardo, L. J. J. Med. Chem. 2006, 49, 3766.

4. Helal, C. J.; Sanner, M. A.; Cooper, C. B.; Gant, T.; Adam, M.; Lucas, J. C.; Kang, Z.; Kupchinsky, S. Ahlijanian, M. K.; Tate, B.; Menniti, F. S.; Kelly, K.; Peterson, M. Bioorg. Med. Chem. Lett. 2004, 14, 5521.

5. Li, M.; Sim, Y.; Ham, S. W. Bull. Korean Chem. Soc. 2010, 31, 1463.

6. www.millipore.com/drugdiscovery/KinaseProfiler

7. TrkA kinase assay: A $15 \mu \mathrm{L}$ solution with a final assay concentration of $250 \mu \mathrm{M}$ substrate (KKKSPGEYVNIEFG) and approximately $10 \mathrm{ng}$ of active $\mathrm{N}$-terminal $6 \mathrm{His}$-tagged recombinant human TrkA (residues 440-end, $41 \mathrm{kDa}$ ) in $8 \mathrm{mM}$ MOPS ( $\mathrm{pH} 7.0$ ), $0.2 \mathrm{mMEDTA}$, $0.5 \%$ glycerol, $0.001 \%$ Brij-35, $0.01 \%$ 2-mercatoetnanol, and $1 \mathrm{mg} /$ $\mathrm{mL}$ BSA was placed in a 96-well microtitier plate. The contents were mixed gently, and various concentrations of compound $\mathbf{H 1 5 4}$ dissolved in DMSO were then added to the reaction mixture. After adding $10 \mu \mathrm{L}$ of $25 \mathrm{mM}$ magnesium acetate and $0.25 \mathrm{mM}$ $\left[\gamma_{-}{ }^{33} \mathrm{P}\right] \mathrm{ATP}$ (specific activity approximately $500-800 \mathrm{cpm} / \mathrm{pmol}$ ), the reaction mixture was incubated for 10 minutes at $30{ }^{\circ} \mathrm{C}$. The reaction was quenched by adding $5 \mathrm{~mL} \mathrm{3 \%}$ phosphoric acid and 10 $\mu \mathrm{L}$ aliquot transferred onto the appropriate area of a P30 filtermat. The filter mat was washed three times with $75 \mathrm{mM}$ phosphoric acid for 5 minutes each, and once with methanol, and transferred to a sealable plastic bag. After adding $4 \mathrm{~mL}$ of a scintillation cocktail, the enzyme activity was read in a scintillation counter. The cpm of the enzyme sample with various concentrations of $\mathbf{H 1 5 4}$ was compared with that of the control samples that containing all assay components plus $1 \mathrm{~mL}$ of $30 \%$ phosphoric acid.

8. Tripathy, R.; Angeles, T. S.; Yang, S. X.; Mallamo, J. P. Bioorg. Med. Chem. Lett. 2008, 18, 3551, and references there in.

9. Wang, T.; Lamb, M. L.; Scott, D. A.; Wang, H.; Block, M. H.; Lyne, P. D.; Lee, J. W.; Davies, A. M.; Zhang, H. J.; Zhu, Y.; Gu, F.; Han, Y.; Wang, B.; Mohr, P. J.; Kaus, R. J.; Josey, J. A.; Hoffmann, E.; Thress, K.; Macintyre, T.; Wang, H.; Omer, C. A.; Yu, D. J. Med. Chem. 2008, 51, 4672, and references there in.

10. Revill, P.; Serradell, N.; Bolos, J.; Rosa, E. Drugs Future 2007, $32,215$.

11. Marshall, J. L.; Kindler, H.; Deeken, J.; Bhargava, P.; Vogelzang, N. J.; Rizvi, N.; Luhtala, T.; Ratain, M. J. Investig. New Drugs 2005, 23, 31 .

12. Weeraratna, A. T.; Arnold, J. T.; George, D. J.; DeMarzo, A.; Isaacs, J. T. Prostate 2000, 45, 40.

13. Florenes, V. A.; Malanddsmo, G. M.; Holm, R.; Reich, R.; Lazarovici, P.; Davidson, B. Am. J. Clin. Pathol. 2004, 122, 412.

14. Davidson, B.; Reich, R.; Lazarovici, P.; Nesland, J. M.; Skered, M.; Risberg, B.; Trope, C. G.; Florenes, V. A. Clin. Cancer Res. 2003, 9, 2248.

15. Zhang, Y.; Dang, C.; Ma, Q.; Shimahara, Y. Oncol. Reports 2005 , $14,161$.

16. Barreau, F.; Cartier, C.; Ferrier, L.; Fioramonti, J.; Bueno, L. Gastroenterology 2004, 127, 524.

17. The cytotoxicity test was performed in vitro at the Korea Research Institute of Chemical Technology using the SRB (sulforhodamine B) method. 